\title{
The Dialectic of Nationalism and Democratic Governance in Taiwan
}

\section{CHRISTIAN SCHAFFERER ${ }^{*}$}

Taiwan's postwar political system has undergone manifold changes leading to distinct modalities of democratic governance. This paper argues that the key to understanding and conceptualizing the dynamics behind the evolution of the island republic's different modi operandi of democratic governance lies in the dialectic of Taiwanese nationalism that emerged over several decades in response to historical and political circumstances. Specifically, this paper investigates how this dialectic shaped two distinct patterns of democratic governance (statecentric vs. human-centric) over time and how this process was influenced by public discourses as well as historical contingencies. Furthermore, the paper elaborates on why humancentrism is more likely to safeguard democratic development and regional security than China-centrism.

Keywords: Taiwan, Ethnic Nationalism, Civic Nationalism, Governance, Democracy, Chen Shui-Bian

* Professor, Overseas Chinese University, Taichung, Taiwan;

E-mail: chris@fule.at

DOI: $10.16934 /$ isr.17.2.201612.159 


\section{INTRODUCTION}

Taiwan is one of the few third-wave democracies in Asia that have for a couple of decades been uninterruptedly categorized as a liberal democracy by international political observers and renowned institutions such as Freedom House. During the last two decades, the island republic has not only witnessed a peaceful transfer of executive power for three times and cultivated a vibrant democratic society, but also developed its own distinct form of democratic governance that could serve as a role model for other young democracies.

In this section of the paper, I would like to recapitulate previous political research on Taiwan's democratic governance to illustrate the need for more profound analysis beyond the re-occurring issue of cross-strait relations that has overshadowed discussions on Taiwan ever since. Previous research on democratic governance in Taiwan predominately investigated the behavioral, institutional and attitudinal components thereof. As to the first, political analysts endeavored to evaluate democratic governance and predict future political scenarios by analyzing elite behavior. Most of the research in this category has, however, been guided by normative post-war conceptions of how political elites ought to behave under the "One-China" framework. That is, the quality of democratic governance has been interpreted as a function of elite commitment to the framework rather than seen as a reflection of actual elite policies. This methodological fallacy was especially obvious during Chen Shui-bian's term in office (Copper 2003, 2009; Ku 2008). Institutional research has focused on constitutional barriers to democratic governance by addressing issues of "divided" government (Chen and Huang 1999; Huang 2006; Chu 2016; Hawang 2016). Attitudinal research has in general applied Morlino's (2004) trinity notion of good democratic governance to interpret survey results on popular perceptions of political corruption, trust in government, and democratic legitimacy as well as satisfaction with democratic governance (Chang et al. 2007; Chang et al. 2011; Huang 2011). Although the importance of opinion polls in evaluating governance cannot be denied, it is doubtful whether the implications of government policies for democratic development can satisfactorily be gauged by referring to perceived corruption and satisfaction indexes.

To recapitulate, contemporary research on democratic governance in Taiwan has independently focused on various aspects. In this study, however, I would like to conceptualize Taiwanese democratic governance by unifying its behavioral, institutional and attitudinal components.

Specifically, I argue that the key to understanding and conceptualizing the dynamics behind the evolution of the island republic's different modi operandi of democratic governance lies in the dialectic of Taiwanese nationalism that emerged over several decades in response to historical contingencies. In subsequent sections of this paper, I illustrate how this dialectic shaped two distinct patterns of 
democratic governance (state-centric vs. human-centric) over time and how this process was 'guided' by historical contingencies. I also elaborate on why humancentrism is more likely to safeguard democratic development than China-centrism.

\section{CIVIC VS. ETHNIC NATIONALISM}

Research on nationalism has led to the widely accepted distinction between civic and ethnic nationalism, which is firmly rooted in the dichotomy between traditional and modern societies. That is, the two forms of nationalism are seen as "a function of socio-economic and intellectual conditions" (Lecours 2000, 155). This dichotomy dates to earlier works on nationalism. Kohn (1944) observed a fundamental difference between nationalism in the West (Western Europe and the USA) and the East (Eastern Europe and Asia). In the former, a pluralist and progressive form of nationalism emerged because of liberal values and institutions; whereas in the absence of such values and institutions ethnocentric nationalism dominated the East. Kohn $(1944,574)$ described the progressive form as building on "a rational and universal concept of political liberty and the rights of man," and Eastern nationalism on history, monuments, graveyards and tribal solidarity. Ethnic nationalism is thus seen as the nationalism of the unenlightened (Lecours 2000, 155). The political consequence of ethnic nationalism would be a world of culturally homogenous states, where membership is decided at birth. Civic nationalism, on the other hand, neither pursues nor requires cultural homogeneity. Membership is open to any individual committed to the values of the political space.

Although the ethnic-civic distinction is considered a useful analytical tool in political research (Breton 1988; Ignatieff 1993), it should be seen as two ends of a continuum, since probably all nations have both civic and ethnic elements (Bretton 1988; Smith 1991; Zimmer 2003). The identity of states could thus be classified as either predominantly civic or predominately ethnic.

\section{THE EVOLUTION OF TAIWANESE NATIONALISM}

When the Chinese nationalist (KMT, Kuomintang) government arrived in Taiwan, its state doctrine was the promotion of ethnic Greater Han Chinese nationalism. The indigenous cultures of the population were considered inferior and local languages were forbidden (Windrow 2005). Nevertheless, there was a growing Taiwanese consciousness that developed into a political movement with the aim of challenging the KMT's Sino-centric Han chauvinism by cultivating Taiwanese subjectivity. Taiwanese nationalists argue that Taiwan's history has been a history of "peripheralization." That is, the Taiwanese people have never been a "subject" in history, only "an appendage of someone else's subjectivity"-whether Manchu Qing Empire (1683-1895), the Japanese Empire (1895-1945), or Republi- 
can China (since 1945) (Lynch 2004, 517). The state of 'peripheralization' manufactured the belief of a pre-given identity or state essentialism-something with which the people of Taiwan would have to reconcile. However, no nation is essential (Anderson 1983). Nation-states are "exogenously constructed entities, and individuals involved in state and policy formation are enactors of scripts rather more than they are self-directed actors" (Meyer et al. 1997, 150). Growing Taiwanese consciousness challenged the propagated KMT narratives of essentialism and led to the conviction that Taiwan can also be a subject in history as much as other nations are, and that Taiwan can enjoy the right to determine its own future collectively and autonomously, free of outside pressures (Lynch 2004, 517).

The nature of Taiwanese nationalism has changed considerably over time. In the late 1970s, it appeared mostly in its primordial form (Song 2004), whereas in the early 1990s its political dimension started to surface as a result of democratization (Wong 2001). Using the concept of "prospective rationality," Hsu Yung-ming and Fan Yun (2001) argue that identity formation in the late 1990s was no longer driven by historical constraints or collective memory but has developed into a "learning process involving rational calculations regarding the future" (Wang 2012, 108). Chen Rou-Lan (2012) elaborates on this transformation in her analysis on the evolution of national identity in Taiwan. She asserts that the concept of national identity contains two dimensions: the primordial and the political. The first refers to "affiliation and solidarity with one's own ethnic community" and the latter refers to "loyalty to a political unit in terms of citizenship and boundaries" (846). Empirical findings of her confirmatory factor analysis show that the meaning of national identity changed during the observed timeframe from 1992 to 2004: During Lee Teng-hui's term in office (1988-2000), political nationalism emerged as an important component of national identity, whereas it became the dominant dimension under Chen Shui-bian (2000-2008) (870).

Taiwanese scholars, such as Lin $(1989,2000)$, Hsu and Fan (2001), see Taiwanese nationalism as an end and democracy with its institutions as a means. Democracy should help the people of Taiwan to obtain justice, to deal with the past and to end the dominance of "outside" (Chinese or, for that matter, American) forces in determining nationhood and their collective future. In other words, democratization is seen as a process of "learning to be Taiwanese"-a process of self-liberation and self-emancipation (Hsu and Fan 2001).

Although democracy has been viewed as a means, it has actually transformed Taiwanese nationalism. That is, it has sidelined the ethnic component and developed its civic characteristics. Wong $(2001,178)$ concludes in his analysis on Taiwanese nationalism that the "function of liberal democracy has been to transform Taiwan's ethnic particularism into an emergent inclusive civic nationalism." Taiwanese nationalism in its current civic form envisages a nation that is 
open to all people who consider Taiwan their home, identify with Taiwan, and are willing to struggle for Taiwan, regardless of their race, ethnicity, or religion (Shih 2001). The emphasis is thus on loving Taiwan, not on blood and cultural ties of the Chinese nation. Taiwanese nationalism is, however, exclusive to those who "identify with Taiwan but more with China," since "they have chosen to belittle the Taiwanese identity and to regard Taiwan as a future administrative region of China, not as an autonomous nation" (Lynch 2004, 526).

Qi $(2012,982)$, in his multivariate analysis on national identity and popular support for de-jure independence of Taiwan, showed that the number of people identifying themselves as Taiwanese (not Chinese) increased constantly from 17.6 percent in 1992 to 52.7 percent in 2010 (Chinese identity dropped from about 20 percent to below 5 percent and the remaining citizens favored a dual identity). Support for de-jure independence rose from 12 percent in 1994 to 23 percent in 2010. The last indicator is however a "repressed opinion," because respondents take the consequences of such a policy option into consideration. By rephrasing the question, i.e. include the assumption that Chinese government would accept de-jure independence, over 51 percent of the respondents in a nationwide crosssectional survey conducted in 2003 supported independence (Qi 2012, 981). The most interesting finding was that the number of people identifying with the Democratic Progressive Party (DPP) dropped considerably during Chen Shui-bian's term in office, whereas support for de-jure independence increased and Taiwanese identity experienced a constant rise as well. This trend continued even after the return of the KMT in 2008, suggesting that "the DPP's monopoly on Taiwanese nationalism has been weakened" (991). The Sunflower Movement and its political wing, the New Power Party, further challenged the DPP's monopolistic position, especially among the young Taiwanese. As a matter of fact, it has been the Sunflower Movement that has strengthened the civic character of Taiwanese nationalism in the post-Chen Shui-bian era rather than the DPP.

\section{THE DISCOURSE ON TAIWANESE NATIONALISM}

The intertwined issue of nationalism, national identity and cross-strait relations has been a seemingly indispensable part of the discourse on Taiwanese politics. The following section of this paper gives an overview of how Taiwanese nationalism was perceived during Chen Shui-bian's term in office, when the debate reached new levels of intensity.

The international community praised the election victory of Chen Shui-bian (DPP) as a major step towards democratic consolidation in Taiwan. It did not take long, however, for political analysts to highlight the potential threats posed by Chen and his "nationalist" ambitions to peace and security in Asia. In 2001, Campbell and Mitchell $(2001,15)$, for example, wrote in Foreign Affairs that Beijing 
was alarmed by "the rising tide of Taiwanese nationalism," and that "perhaps nowhere else on the globe is the situation so seemingly intractable and the prospect of a major war involving the United States so real." The discourse on Taiwanese politics has been hijacked by this assertion, rendering any genuine analysis on the true nature of Taiwanese nationalism and its implications for democracy superfluous or even undesirable.

The general narrative was that Taiwanese nationalism was primordial rather than civic, and that Chen Shui-bian played the 'ethnic card' to win popular support, which agitated tensions with China and led to a deterioration of democracy. Wu (2004, 614), for example, asserts that Taiwanese nationalism-contrary to Chinese nationalism-is primordial since it propagandizes an exclusive Taiwanese identity. That is, the KMT espoused nationalism "treats the Taiwanese people as a constituent part of the Chinese people, Taiwanese culture as a branch of culture, and the Taiwanese languages as mere dialects." Chinese nationalism is thus inclusive of Taiwan. Taiwan nationalism, on the other hand, "asserts that China is an alien entity" and is thus not inclusive of China. Wu also echoed the widespread assumption that the inexorable rise of Taiwanese nationalism experienced under Chen Shui-bian was predominantly "the result of government engineering orchestrated by top leaders" (elite politics contingent thesis) rather than a genuine identity change as a result of socio-political changes (structural thesis) (Wu 2004, 620).

Apart from a seemingly inevitable war with China, foreign experts observed the "devolution" of the island republic's democracy. Copper $(2009,463)$, for example, asserted that "civil liberties deteriorated owing to Chen playing ethnic politics as well as his administration's lack of respect for democratic values." Domestically, criticism in the same vein came from Chinese nationalists who perceived the move away from China-centrism (de-Sinification) as racial persecution. Since the early 1990s, influential personalities of the Taiwanese nationalist movement, such as Chen Shui-bian, have thus frequently been branded "fascists," or compared with the world's most infamous (non-Chinese) dictators. In 1994, influential Chinese nationalist Chao Shao-kang yelled at Chen Shui-bian during a live televised election debate, calling him a fascist. Years later, the KMT compared Chen with Mussolini in an official televised electoral campaign commercial, and in the 2004 presidential election campaign, the KMT-led coalition initiated a media barrage against President Chen. More than a dozen different ads were placed in Taiwan's leading newspapers and aired by major television stations, most of which were entitled "Change the President, Save Taiwan." The tone and language used in the opposition's campaign leaflets and ads were rather unprecedented in a presidential election campaign. Newspaper ads even compared President Chen Shui-bian with Adolf Hitler and asked the electorate to end Chen's dictatorship by voting for the opposition. A photo of Hitler was added to drive home the insinuation. In central Taiwan, the KMT campaign headquarters distributed posters showing terrorist Bin 
Laden expressing his admiration of Taiwan's "dictator" Chen. In another ad, an image of former Iraqi President Saddam Hussein was used to convey similar messages. The perceived persecution of "ethnic Chinese" and the rise of Taiwan's "Adolf Hitler" became the most debated issue among Chinese nationalist scholars and grassroots supporters at the time. Publications detailing the "similarities" between the rise of Hitler and Chen Shui-bian mushroomed and were sold in bookstores throughout the island republic. One of the most popular publications was Shuddering Future: Dismantle Taiwan's New Dictatorship (Huang 2004), in which the author discussed in detail the rise of Taiwan's "Hitler" and urged readers to assist the new democracy movement in protecting democracy in Taiwan. The front cover of the publication showed a silhouette of Chen Shui-bian and a modified DPP party emblem in the shape of a swastika. The book was endorsed by a large number of popular intellectuals and newly-established "civil-rights" groups, such as the Democratic Action Alliance led by a group of university professors. In addition to the local discourse, the overseas Chinese community in the United States expressed their deep concern about the decay of democracy, i.e. the "persecution of Mainlanders," because of an inexorable rise of Taiwanese nationalism. The Taiwan Civil Rights Watch Group based in Washington D.C., for example, concluded its 2004 report on human rights abuses in Taiwan with the assessment that "Taiwan is well on its way toward a dictatorial holocaust" (Taiwan Civil Rights Watch Group 2004, 20).

Despite the xenophobic climate, there were several scholars depicting a less dramatized picture. Taiwan's leading political scientist Chu $(2004,486)$ emphasized that neither "the principled believers in unification nor the principled believers in independence" could outnumber the non-committed rationalists. He argued that the popular predilection for de-jure independence had been constrained by "an updated perception of China's economic potential and growing awareness of the inevitability of greater cross-strait economic integration,"-a trend most visible among the younger generation despite "intensified efforts by the incumbent elite to sway the populace in a pro-independence direction" (486). Robert S. Ross (2006) questioned that the Taiwanese identity was the dominant trend among the Taiwan-born population, and argued that the dual "Taiwan-China" identity was increasingly gaining popularity instead. Such tendency would be especially evident among younger Taiwanese, who according to Ross $(2006,452)$ were "increasingly" attracted to Chinese universities and "increasingly find[ing] work and eventual career success" in China. Furthermore, he believed that as the number of Taiwanese who had experienced violent mainlander repression on Taiwan dwindled, intense anti-China sentiments would become rare and a growing portion of people with positive experiences in dealings with China would take its place. Ross also saw in the growing popular dissatisfaction with Chen's mainland policy the reason for the DPP's election defeat in the 2004 parliamentary election, and concluded his 
analysis predicting the "demise of the Taiwan independence movement" (457).

Other scholars, such as Gunter Schubert (2004), Timothy Wong (2001) and Song Xiaokun (2011), offered a more nuanced analysis and acknowledged the civic nature of Taiwanese nationalism. Schubert (2004) argued that Taiwanese as well Chinese nationalists were "civic and liberal" and that there was a rise of an "overarching consensus" between elites as to the political future of Taiwan. It therefore would "not make much difference which party governs the island" (535). He also asserted that Taiwan was "ready to open up to the mainland and allow for economic and political integration" (538). Wong (2001) and Song (2011) traced the cultural and political origins as well as the changing characteristics of Taiwanese nationalism over time. The concluding part of their analyses reiterates the fact that the civic nature of Taiwanese nationalism requires subjectivity while offering reminders that such subjectivity has historical restrictions. Wong (2001, 201) thus recommends Taiwan to form a union with China that is supposed to "approximate the Habermasian ideal of a universal practice of citizenship." Acknowledging the positive effects Taiwanese nationalism has had on Taiwan's society, Song $(2011,226)$ asks for caution since "the predominance of the civic nationalist discourse does not necessarily mean that it is more inclusive and morally desirable." He argues that the exclusive understandings of sovereignty and territorial integrity inherent in the concept of Taiwanese nationalism has "augmented" cross-strait tensions, which might have severe consequences for security and stability in the Asia-Pacific region (226).

\section{MODI OPERANDI OF DEMOCRATIC GOVERNANCE}

In general, any form of governance is subject to historical and agentic contingency. Before discussing the agents shaping democratic governance in Taiwan, attention should be given to the exceptional historical constellation (historical contingency) under which democratic governance evolved: During the Cold War, Taiwan played an important role in the US policy of containing Asian communism. Its geostrategic position and the fact that the KMT government represented China at the United Nations and was therefore entitled to occupy one of the permanent seats at the Security Council provided the KMT with almost unconditional support from the United States. In 1949, Mao Zedong proclaimed the People's Republic of China as the de-facto and de-jure successor state of the KMT's Republican China. Although the KMT government only had de-facto jurisdiction over Taiwan, Kinmen and the Pescadores, it continued to claim to be the sole legitimate government of China. The US government was instrumental in preserving the KMT's legitimacy on the international floor (Luard 1971). It successfully defended the KMT's right to represent China at the UN until 1971, when UN Resolution 2758 was passed to expel "the representatives of Chiang Kai-shek from the place which 
they unlawfully occup [ied] at the United Nations" and "to restore the rights of the People's Republic of China and to recognize the representatives of its Government as the only legitimate representatives of China to the United Nations." Notwithstanding, it was not before 1978 that the US switched diplomatic recognition to Beijing, acknowledging Beijing's position that Taiwan is part of China.

This mutual understanding constitutes the illiberal framework under which democratic governance of the island republic can be exercised. The framework, i.e. Washington's One-China policy, is predominately the result of postwar policies attempting to deny the existence of the People's Republic of China, and has its roots in the so-called China Lobby (Koen 1974; Accinelli 1996). Historically, China itself was less of an aggressor than a victim in the dispute and thus eager to eventually become a beneficial occupant of the framework. The evolution of democratic governance in Taiwan has been guided by this historic contingency. The following analyses the objectives of the key actors involved in shaping the different modalities of governance (agentic contingency).

Classic state-centric governance: The US viewed Taiwan as first and foremost a theater of Cold War politics. That is, the KMT regime was instrumental in containing China and in exchange was offered financial and military assistance. During the Cold War, the focus of governmental policies in Taiwan was thus on economic growth and national security. The government was reluctant to introduce democracy and its leaders possessed limited appreciation of liberal values $(\mathrm{Wu}$ 2004). The rise of China, Taiwan's expulsion from the UN, the global democratic mood of the late 1980s, and a politically more demanding society due to rapid socio-economic development laid the foundation for significant changes in the modus operandi of governance, turning the "soft authoritarianism" (Winckler 1984,481 ) of the 1980s into democratic governance within a decade.

Human-centric governance: President Lee Teng-hui (1988-2000) grasped the Zeitgeist and was the first president to attempt abandoning state-centric development. Lee was an outspoken critic of the "Asian value" meme (Barr, 2000). Under his presidency, major political reforms were carried out, turning Taiwan into a full-fledged democracy (Dickson and Chao 2002). He pursued a proactive foreign policy intended to make the world aware of Taiwan's democratic and economic achievements, aspirations and unfulfilled ambitions, and gave up previous claims of representing China in international affairs (Huang 2003).

Under Lee's successor, Chen Shui-bian of the Democratic Progressive Party (DPP), Taiwan de-facto shifted away from Cold War state-centric policy making. President Chen had a vision of a cosmopolitan island republic that should work toward establishing the values of shared prosperity and respect for the rule of law. Chen ardently promoted human-centric governance with the aim of turning Taiwan into Asia's most democratic state while at the same time sharing in the global attempt to protect and promote human rights internationally. His government pro- 
posed several important actions: (1) the establishment of an independent national human rights commission based on the Paris Principles; (2) the abolition of the death penalty; (3) the ratification of two international human rights covenants (UN covenants on Civil and Political Rights and Economic, Social and Cultural Rights) and their codification into national legislation; and (4) enforcing transitional justice (Schafferer 2010, 2013). As to international relations, Taiwan under Chen strove vigorously for a more active role in the international community by joining international organizations. During Chen's term in office, Taiwan expanded its membership in international governmental organizations from 16 to 26 (Larus 2006, 32). Chen also wanted to see Taiwan's democracy spread to neighboring states and serve as a model of democratic success. In 2003, the Ministry of Foreign Affairs founded the Taiwan Democracy Foundation. The foundation offers financial assistance to democratic projects overseas and publishes a number of academic journals. In the same year, the Democratic Pacific Union was established. The main aim of the organization was to consolidate democratic values, foster human development and safeguard regional security. The organization worked to increase the number of states in the region that shared Taiwan's desire for democratic development, peace and security. Taiwan wanted to become the region's "exporter of democracy" (43). Under Chen, Taiwan also took a more active role in foreign aid. Beyond its traditional technical and economic aid, government agencies began in 2001 to participate in humanitarian assistance abroad (Wang and Lu 2008, 443; Guilloux 2009). Moreover, Tubilewicz and Guilloux $(2011,326)$ noted that the DPP government "declared its rejection of the KMT's dollar diplomacy and emphasized democracy and human rights as the 'new basis' for Taiwan's foreign policy."

China-centric governance: In 2008, Ma Ying-jeou of the Nationalist Chinese Party (Kuomintang, KMT) won a landslide victory in the presidential election. His victory was praised by the international community as a major step towards peace and security in East Asia (Gold 2009). The KMT had run its electoral campaign primarily on the issue of economic cooperation with the PRC and conveyed the message that a rapprochement with the Beijing government would (1) maintain peace and security in East Asia; (2) increase Taiwan's international space; (3) allow Taiwan meaningful representation in international bodies; (4) permit Taiwan to sign FTAs with other countries; and (5) accelerate Taiwan's economic growth (Muyard 2010, 7-8). Domestically, the change of government in 2008 brought about a revival of Chinese nationalism, putting an end to the former government's envisaged cosmopolitan state (7-8), reversing efforts toward transitional justice (Schafferer 2013), and returning Taiwan to a state-centric environment with emphasis on economic growth (Chung 2009). In international affairs, the narratives that Taiwan's public diplomacy broadcast to the world shifted. Under the DPP, Taiwan had been an exporter of democracy. The main aim of Ma's public 
diplomacy was to portray Taiwan as a "preserver of traditional Chinese culture." The new narrative included strategies such as dispatching exhibitions of traditional Chinese calligraphy around the world (Rawnsley 2014, 170). The shift was also reflected in the upgrading of the Council of Cultural Affairs from a committee under the Executive Yuan, the executive branch of the Taiwan government, to a full-fledged ministry in 2012.

\section{THE DIALECTIC OF NATIONALISM AND NATION BUILDING}

The modalities of governance are intertwined with the dialectic of nationalism and reflected in the three waves of nation-building with each "possessing its own way of defining national status and (re)inventing a distinct community" (Yeh 2014, 209). During the first wave, Taiwan officially served as a "sacred bastion" to recover China and was part of a greater imagined Han Chinese community to be ruled by the KMT government.

The second wave of state-sponsored nation building began under Lee Tenghui (Corcuff 2002). The new wave changed the status of Taiwan from a sacred bastion to a valid nation in and of itself, searching for self-identity and striving for the acknowledgment of the international community. Taiwanese nationalism became the official state doctrine. Lee Teng-hui redefined nationalism by proposing the concept of "New Taiwanese" in the mid-1990s. The new concept deconstructed Chinese pride, called for a de-Sinification of Taiwan and cultivated a new nationness with the aim of defining nationalism as something being beyond ethnic identity. The concept of "New Taiwanese" emphasized political identification with Taiwan as an independent state while gradually neglecting ethnic origin. Lee Teng-hui's "New Taiwanese" referred to those Mainlanders who called Taiwan home. Chen Shui-bian expanded the meaning by including all new immigrants, especially from Southeast Asian countries. In his inaugural speech in May 2004, he put emphasis on the fact that Taiwan had over the last few centuries become the home of migrants with different cultural and ethnic backgrounds and that Taiwan was transforming into a multi-ethnic society. Chen Shui-bian's concept of Taiwanese nationalism thus even more sidelined the ethnic component and envisioned a cosmopolitan Taiwan nation-state. Political identification with Taiwan as an "independent" nation-state replaced ethnic Chinese nationalism.

During the third wave of state-sponsored nation-building under Ma Yingjeou, a "practical-yet-pro Chinese nationalism" was adopted (Yeh 2014, 219). That is, Ma downplayed the significance of both the ethnic and the political dimensions of national identity, and placed great importance on economic cooperation with the Mainland. This form of nation-building promoted economic nationalism or loyalty to the Chinese economic community. 


\section{CONCLUSION AND DISCUSSION}

Taiwan's postwar political system has undergone manifold changes leading to two distinct forms of democratic governance with different possible trajectories. During the Cold War, classic state-centrism was the sole modus operandi of governance. The intrinsic value of governance was the protection of the state. During Lee Teng-hui's presidency (1988-2000), a new modus operandi evolved, transcending state centrism and leading to democratic governance. The humancentric approach was consolidated under Chen Shui-bian (2000-2008). His successors, Ma Ying-jeou (2008-2016) terminated the cosmopolitan project and vigorously promoted China-centrism.

From the perspective of democratization theories, Chen Shui-bian's humancentrism would be considered a crucial contribution to democratic consolidation. Democratic peace theory would praise his human-centrism as a step towards international peace. Contrary to such theoretical assumptions, Taiwan's humancentric form of governance has remained a footnote at best and its protagonists "trouble makers" at worst. In this paper, I have investigated the domestic as well as international dynamics behind this phenomenon. That is, I have studied alternative discourses and how they worked in resistance to the dominant knowledge to understand genuine developments in a more nuanced way (Milliken 1999). The following is a summary and discussion of the main findings.

As explained in the previous sections of this paper, the distinct modalities of democratic governance are the results of separate waves of nation building, which in turn are grounded on the dialectic of nationalism. Two competing nationalisms in Taiwan have shaped national identity: a Greater Han Chinese nationalism and a Taiwanese nationalism. The first is ethnic nationalism that has been promoted by the Chinese nationalist (KMT) government with the aim of eventual "liberalization of the Mainland" (Windrow 2005, 412). The latter developed out of a growing Taiwanese consciousness and turned into a political movement, challenging Chinese nationalism by cultivating Taiwanese subjectivity. It believes in the power of democracy to deliver justice, to deal with the past, and to end the dominance of "outside" forces in determining nationhood and Taiwan's collective future. Although democracy was supposed to merely function as a means in the whole process, it has transformed primordial Taiwanese nationalism into its current civic form. Chinese nationalism, on the other hand, has had different trajectories. Lee Tenghui transcended the ethnic component of Taiwanese nationalism by pro-claiming his concept of "New Taiwanese," and, in a more subtle way, attempted to tone down the Chinese nationalist rhetoric of the KMT party apparatus. However, after his resignation from the KMT chairmanship in 2000, more conservative Chinese nationalists resumed leadership and eventually returned the party to the Cold-War concept of ethnic Greater Han Chinese nationalism with its imperialistic claims to 
be the legitimate government of China-inclusive of Taiwan, Tibet and Mongolia.

The two modalities of nationalism have had different implications for the nature of democratic governance in Taiwan-implications that are explained by political theory as well as history. Ethnic nationalism, as a form of primordial identity politics, believes identity to be the condition of action, whereas civic nationalism interprets identity as the product of action. For political theorist Hannah Arendt, genuine political action "is based on the fact of human plurality" (Arendt 2005, 93). Human plurality is "not only the conditio sine qua non, but the conditio per quam" (Arendt 1998, 7) of all political life and secures our status as fully human beings (Arendt 2005, 115). Since ethnic nationalism conditions political actions, it denies human plurality. Civic nationalism, on the other hand, requires plurality in action. Moreover, the genuine political arises between different, distinct individuals because of their interactions and interrelationships expressed through speech (lexis) and action (praxis) (Arendt 1998, 25, 177), and it is only there where freedom exists (Arendt 2005, 95). Action and speech must be authentic, i.e. spontaneous and create something unpredictable and new (Arendt 2006, 150). Nationalism as an ideology, however, forecloses spaces of action and speech, because it "systematically sets out to destroy any possibility of the unpredictable or the new" (Birmingham 2002, 194; 2006). It is the apolitization of the political and the subsequent extension of the social sphere that creates the monolithic character of society, allowing "for only one interest and one opinion" and "threaten[ing] humanity with extinction" (Arendt 1998, 46). Chinese nationalism as a KMT state doctrine is still supposed to reinforce through education "the Chinese/Confucian notions of conformity and citizen's responsibility to comply with top-down directives," (Cole 2015, 3291) with educators "drill[ing] such concepts into the minds of their students, discouraging them from caring about politics and berating them (often by calling their parents) if they do not comply" (3297). This apolitization of society encapsulates the chasm that continues to exist between Chinese and Taiwanese nationalism.

Apart from the dialectic of nationalism, the evolution of democratic governance has been substantially shaped by historic contingency, i.e. Washington's One-China policy. The policy in effect has granted Taiwan Westphalian sovereignty while curtailing its international legal sovereignty. Since the US recognition of the Beijing government as the sole legitimate government of China in 1978, Taiwan has been trapped in the One-China framework. China, once a victim of the framework, has become its beneficial occupant as well as a potential aggressor. Notwithstanding, it has mostly been the United States that has framed the narrative and has overtly objected to anything that might endanger the status quo in the Taiwan Strait. After all, it was President George Bush who publicly warned Taiwan of committing "grave errors" and posing "threats to regional security"not his counterpart in Beijing. Consequently, the rise of Taiwanese nationalism 
and President Chen Shui-bian vision of a cosmopolitan state seeking to extent its international space were interpreted as a serious threat to the "framework."

As illustrated in previous sections of this paper, political analysts asserted that Chen's ethnic nationalism further "aggravated" the already tensioned relationship with China and "divided" Taiwan's society. In retrospect, both narratives might well have been the result of "discursive bandwagoning" of ahistorical analyses, overestimating the aggravation as well as the division, as Johnston (2013) explained in his work on China's "new" assertiveness. I argue in this paper that in the search for alternative discourses, a different and probably more explanatory picture of democratic governance and Taiwanese nationalism may be obtained. Genuine research should focus on domestic realities rather than on formulating normative policies and directives on how to maintain the "framework." As pointed out earlier, even existing genuine research, such as Wong (2001) and Song (2011), never falls short of reminding Taiwan of its historical obligation to restrict its subjectivity and eventually re-unite with China. However, calls for eventual "political integration" with China "modeled" on the European Union or similar suggested constructions that "should approximate the Habermasian ideal of a universal practice of citizenship" (Wong 2001, 201) de-facto lead to annexation. The European Union is foremost a community of states exercising pooled sovereignty and predicated on common democratic values. The Habermasian ideal of citizenship (Habermas 1994) evolved through studies of the European continent and the emergence of the European Union. This concept of citizenship should thus be seen in the European context and as an indispensable part of democratic rule and pooled sovereignty. Moreover, Tibet and Hong Kong unambiguously exemplify China's notion of "pooled sovereignty" and citizenship, rendering any further discussion pointless. Democratic peace theory is also unambiguous and would conclude that Taiwan's human-centrism should not be sanctioned. It should be appreciated and incorporated into a new Asian security framework. The case of Taiwan illustrates that the postwar US foreign policy towards East Asia is obsolete, and the pivot to Asia only reinforces the claim of obsoleteness. The only observable change in US policy towards Asia is the shift from containing communism to containing democracy.

\section{REFERENCES}

Accinelli Robert. 1996. Crisis and Commitment: United States Policy Toward Taiwan, 1950-1955. Chapel Hill NC: The University of North Carolina Press. Anderson, Benedict. 1983. Imagined Communities. New York: Verso.

Gilley, Bruce. 2004. "Against the Concept of Ethnic Conflict." Third World Quarterly 25(6): 1155-1166.

Arendt, Hannah. 1998. The Human Condition. 2nd Ed. London: The University of 


\section{Chicago Press.}

Arendt, Hannah. 2005. The Promise of Politics. New York: Schocken Books.

Arendt, Hannah. 2006. Between Past and Future: Eight Essays in Political Thought. London: Penguin Books.

Barr, Michael. D. 2000. "Lee Kuan Yew and the 'Asian values' Debate." Asian Studies Review 24(3): 309-334.

Bruce J. Dickson and Chao Chien-Min (eds.). 2002. Assessing the Lee Teng-hui Legacy in Taiwan's Politics: Democratic Consolidation and External Relations. New York: ME Sharpe.

Birmingham, Peg. 2002. "Heidegger and Arendt: The Birth of Political Action and Speech.” In Heidegger and Practical Philosophy, edited by François Raffoul and David Pettigrew, 191-218. New York: State University of New York Press.

Birmingham, Peg. 2006. Hannah Arendt and Human Rights: The Predicament of Common Responsibility. Bloomington, IN: Indiana University Press.

Breton, Raymond. 1988. "From Ethnic to Civic Nationalism: English Canada and Quebec." Ethnic and Racial Studies 11(1): 85-102.

Campbell, Kurt M. and Derek J. Mitchell. 2001. "Crisis in the Taiwan Strait." Foreign Affairs 80: 14-25.

Chang, Yu-tzung, Chu Yunhan and Pak Chong-min. 2007. "Authoritarian Nostalgia in Asia." Journal of Democracy 18(3): 66-80.

Chang, Yu-tzung, Chu Yun-han and Huang Min-hua. 2011. "Procedural Quality Only? Taiwanese Democracy Reconsidered.” International Political Science Review 32(5): 598-619.

Chen, Don-yun and Tong-yi Huang. 1999. "Divided Government: A New Approach to Taiwan." Issues and Studies 35(1): 1-35.

Chen, Jie. 2002. Foreign Policy of the New Taiwan: Pragmatic Diplomacy in Southeast Asia. Northampton, MA: Edward Elgar Publishing.

Chen, Rou Lan. 2012. "Beyond National Identity in Taiwan: A Multidimensional and Evolutionary Conceptualization.” Asian Survey 52(5): 845-871.

Chu, Yun-han. 2004. "Taiwan's National Identity Politics and the Prospect of Cross-Strait Relations.” Asian Survey 44(4): 484-512.

Chu, Yun-han. 2016. "Strengthening Constitutionalism." In Taiwan's Democracy Challenged: The Chen Shui-bian Years edited by Chu Yun-han, Larry Diamond and Kharis Templeman, 173-194. Boulder, CO: Lynne Rienner.

Chung, Chien-peng. 2009. "The 'Good Neighbor Policy' in the Context of China's Foreign Relations.” China: An International Journal, 7(1): 107-123.

Cole, Michael J. 2015. Black Island: Two Years of Activism in Taiwan. Amazon: Creative Space E-Book.

Copper, John F. 2003. “Taiwan: Democracy's Gone Awry?" Journal of Contemporary China 12(34): 145-162. 
Copper, John F. 2009. "The Devolution of Taiwan's Democracy During the Chen Shui-bian Era." Journal of Contemporary China 18(60): 463-478.

Corcuff, Stéphane. 2002. "Introduction: Taiwan, a Laboratory of Identities." In Memories of the Future: National Identity Issues and the Search for a New Taiwan edited by Stéphane Corcuff. Armonk, NY: M.E. Sharpe.

Gold, Thomas B. 2009. "Taiwan in 2008: my kingdom for a horse." Asian Survey (49)1: 88-97.

Guilloux, Alain. 2009. Taiwan, Humanitarianism and Global Governance. London: Routledge.

Guzzini, Stefano. 2000. "A Reconstruction of Constructivism in International Relations.” European Journal of International Relations, 6(2): 147-182.

Habermas, Jürgen. 1994. "Citizenship and National Identity." In The Condition of Citizenship edited by Bart van Steenbergen, 20-35. London: Sage.

Hawang, Shiow-duan. 2016. "Executive-Legislative Relations Under Divided Government." In Taiwan's Democracy Challenged: The Chen Shui-bian Years edited by Chu Yun-han, Larry Diamond and Kharis Templeman: 123-144. Boulder, CO: Lynne Rienner.

Huang, Eric Ting-lung. 2003. “Taiwan's Status in a Changing World: United Nations Representation and Membership for Taiwan." Annual Survey of International and Comparative Law 9(1): 55-99.

Huang, Min-Hua. 2011. "Popular Discontent, Divided Perceptions, and Political Polarization in Taiwan.” International Review of Sociology 21(2): 413-432.

Huang, Thomas Weishing. 2006. "The President Refuges to Cohabit: Semi-Presidentialism in Taiwan." Pac. Rim L. and Pol'y J. 15: 375.

Huang, Zhi-xian. 2004. Zhanli de weilai: jiegou taiwan xin ducai [Shuddering Future: Dismantle Taiwan's New Dictatorship]. Revised edition. Taipei: Miluo.

Hsu, Yung-ming and Fan Yun. 2001. "Learning to be Taiwanese: The Paths of Forming Taiwanese Identity" (in Chinese). Taiwan Zhengzhi Xuekan 5: 3-63. Ignatieff, Michael. 1993. Blood and Belonging: Journeys into the New Nationalism. Toronto: Viking.

Koen, Ross Y. 1974. The China Lobby in American Politics. New York: Harper and Row.

Johnston, Alastair Iain. 2013. "How New and Assertive is China's New Assertiveness?." International Security, 37(4): 7-48.

Kohn, H. 1944. The Idea of Nationalism. A Study in its Origins and Background. New York: MacMillan.

Ku, Samuel C.Y. 2008. "Political Democratization and Political Crises in Taiwan and the Philippines: A Comparative Perspective." Journal of Contemporary Eastern Asia 7(1): 5-18.

Larus, Elizabeth Freund. 2006 "Taiwan's Quest for International Recognition." Issues and Studies 42(2): 23-52. 
Lynch, Daniel C. 2004. "Taiwan's Self-Conscious Nation-Building Project." Asian Survey 44(4): 513-533.

Lecours, André. 2000. "Ethnic and Civic Nationalism: Towards a New Dimension." Space and Polity 4(2): 153-166.

Lin, Chia-lung. 2000. “Taiwan's Democratization and Party System Transformations" (in Chinese) Taiwan Zhengzhi Xuekan 4: 1-54.

Lin, Chia-lung. 1989. "Taiwan's Opposition Movement under Authoritarianism” (in Chinese) Taiwan Shehui Yanjiu Jikan 2(1): 117-143.

Meyer, John. W. et al. 1997. "World Society and the Nation State." American Journal of Sociology 103(1): 144-181.

Milliken, Jennifer. 1999. "The Study of Discourse in International Relations: A Critique of Research and Methods." European Journal of International Relations 5(2): 225-254.

Morlino, Leonardo. 2004. "What is a 'Good' Democracy?." Democratization 11 (5): 10-32.

Muyard, Frank. 2010. "Mid-Term Analysis of the Ma Ying-jeou Administration." China Perspectives 3: 5-21.

Qi, Dongtao. 2012. "Divergent Popular Support for the DPP and the Taiwan Independence Movement, 2000-2012.” Journal of Contemporary China 21 (78): 973-991.

Rawnsley, Gary. D. 2014 “Taiwan's Soft Power and Public Diplomacy." Journal of Current Chinese Affairs 43(3): 161-174.

Robert S. Ross. 2006. "Explaining Taiwan's Revisionist Diplomacy.” Journal of Contemporary China 15(48): 443-458.

Schafferer, Christian. 2010. "Consolidation of Democracy and Historical Legacies: A Case Study of Taiwan." Journal of Contemporary Eastern Asia 9(1): 2341.

Schafferer, Christian. 2013. "Transitional Justice in Taiwan." In Encyclopedia of Transitional Justice edited by Lavinia Stan and Nadya Nedelsky. (Cambridge: Cambridge University Press).

Schubert, Gunter. 2004. "Taiwan's Political Parties and National Identity: The Rise of an Overarching Consensus." Asian Survey 44(4): 534-554.

Shih, Cheng-feng. 2001. "Taiwan minzuzhuyi de jiexi: zhengzhi mianxiang de sange jingzheng tujing" [Explanations of Taiwanese Nationalism: Three Competing Political Directions]. In Maixiang 21 shiji de taiwan minzu yu guojia lunwenji edited by Chang Yan-hsian et al.: 325-343. Taipei: Wu Sanlian Foundation.

Smith, Anthony D. 1991. National Identity. London: Penguin Books.

Song, Xiaokun. 2004. Between Civic and Ethnic: The Transformation of Taiwanese Nationalist Ideologies (1895-2000). Brussels: Brussels University Press.

Taiwan Civil Rights Watch Group. 2004. 2004 Taiwan's Civil Rights Violation 
Report. Washington DC: Democracy and Truth Alliance.

Tubilewicz, Czeslaw, and Alain Guilloux. 2011. "Does Size Matter? Foreign Aid in Taiwan's Diplomatic Strategy, 2000-2008.” Australian Journal of International Affairs 65(3): 322-339.

Wang, Hun-jen. 2012 "Liberalist Variation in Taiwan: Four Democratization Orientations." Journal of Current Chinese Affairs 41(3): 93-116.

Wang, Hongying and Yeh-Chung Lu. 2008. "The Conception of Soft Power and its Policy Implications: A Comparative Study of China and Taiwan.” Journal of Contemporary China 17(56): 425-447.

Winckler, Edwin. A. 1984. "Institutionalization and Participation on Taiwan: From Hard to Soft Authoritarianism?." The China Quarterly 99: 481-499.

Windrow, Hayden. 2004. "From State to Nation: The Forging of the Han Through Language Policy in the PRC and Taiwan." NYUJ Int'l. L. and Pol. 37: 373422.

Wong, Timothy Ka-ying. 2001. "From ethnic to civic nationalism: the formation and changing nature of Taiwanese identity." Asian Perspective: 175-206.

Wu, Nai Teh. 2004. "Reformer or Dictator? Reassessing the Role of Chiang Ching-guo in the Democratic Transition" (in Chinese). In Proceedings of the Seventh Conference of the National Archives. Taipei: National Archives.

$\mathrm{Wu}, \mathrm{Yu}$-shan. 2004. Taiwanese Nationalism and Its Implications: Testing the Worst-Case Scenario. Asian Survey 44(4): 614-625.

Yeh, Hsin-Yi. 2014 "A Sacred Bastion? A Nation in Itself? An Economic Partner of Rising China? Three Waves of Nation-Building in Taiwan after 1949." Studies in Ethnicity and Nationalism 14(1): 207-228.

Zimmer, Oliver. 2003. "Boundary Mechanisms and Symbolic Resources: Towards a Process-Oriented Approach to National Identity." Nations and Nationalism 9(2): 173-193. 